\title{
CD20-targeted Polypeptide TRU-015
}

National Cancer Institute

\section{Source}

National Cancer Institute. CD20-targeted Polypeptide TRU-015. NCI Thesaurus. Code C70797.

A proprietary antibody-based sing le-chain polypeptide with B cell-depleting activity. Significantly smaller than a whole antibody, CD20-targeted polypeptide TRU-015 binds specifically to the B cell-specific cell surface antigen CD20 with full immunoglobulin Fv fragment-type target binding activity and full immunog lobulin Fc fragment-type effector function. This agent transiently depletes CD20-bearing B cells by inducing B cell-directed complement dependent cytotoxicity (CDC) and antibody-dependent cell-mediated cytotoxicity (ADCC) and B cell apoptosis. 